\title{
PROPOSITION AND EVALUATION OF NATIVE VEGETATION RECOVERING INDEX (NVRI) OF RURAL PROPERTY ${ }^{1}$
}

\author{
Lauro Marino Wollmann ${ }^{2 *}$ and Lia Caetano Bastos ${ }^{3}$
}

\begin{abstract}
${ }^{1}$ Received on 20.06.2014 accepted for publication on 07.03.2016.
${ }^{2}$ Universidade Federal de Santa Catarina, Programa de Pós-Graduação em Engenharia Civil, Florianópolis, SC - Brasil. Email:<lauromarino@hotmail.com>.

${ }^{3}$ Universidade Federal de Santa Catarina, Centro Tecnológico, Departamento de Engenharia Civil, Florianópolis, SC - Brasil. E-mail: <liacbastos@gmail.com>.

*Corresponding author.
\end{abstract}

\begin{abstract}
The new Brazilian Forest Code (Laws no. 12,651/2012 and no. 12,727/2012) establishes a set of rules in relation to native vegetation areas, such as Permanent Preservation Areas and 'Legal Reserve', that must be preserved by the landowner. Thus, it becomes relevant to survey these areas, as well as to assess the need for recovering them. In this context, this research aimed to propose a method for calculating the Native Vegetation Recovering Index (NVRI) for rural properties and to validate it on a case study of Porto Alegre/RS drawing on geotechnology and on a technical cadaster. The method enabled to assess the range of native vegetation and to characterize the Permanent Preservation Areas and the Legal Reserve of rural property, as well as to estimate the fraction of the area to be recovered with native vegetation in each property. In the case study, the calculated NVRI was null for 61 properties, and ranged from $0.1 \%$ to $94.0 \%$ for other 15 properties examined. For properties sized up to 01FM (one fiscal module), the NVRI was $1.3 \%$; for those sized between 01 and $02 \mathrm{FM}$, it was zero; for properties sized between 02 and $04 \mathrm{FM}, \mathrm{NVRI}$ was $1.5 \%$; and for properties above 04FM, it was $10.8 \%$. For the total surveyed properties, the calculated NVRI showed that $9.2 \%$ of the area that should be covered with native vegetation is in need to be recovered, since it is disfigured in terms of its native flora. By enabling to assess the situation of each rural property regarding its compliance with guidelines established in the new Forest Code, the applied method becomes a supporting tool for policies on territorial and environmental management.
\end{abstract}

Keywords: Forest Code; Permanent Preservation Area; Legal Reserve.

\section{PROPOSIÇÃO E AVALIAÇÃO DE ÍNDICE DE VEGETAÇÃO NATIVA A RECUPERAR (IVNR) DA PROPRIEDADE RURAL}

\begin{abstract}
RESUMO-O novo Código Florestal (Leis n. 12.651/2012 e n. 12.727/2012) estabelece um elenco de regras em relação a áreas de vegetação nativa que precisam ser preservadas pelo proprietário rural, como Áreas de Preservação Permanente e Reserva Legal. Torna-se relevante o seu levantamento e a identificação da necessidade de sua recuperação. Neste contexto, esta pesquisa teve como objetivo propor método de apuração do Índice de Vegetação Nativa a Recuperar (IVNR) da propriedade rural com apoio no cadastro técnico e geotecnologias e validá-lo em estudo de caso no município de Porto Alegre/RS. O método permitiu dimensionar a cobertura com vegetação nativa, caracterizar as Áreas de Preservação Permanente e a Reserva Legal, e estimar a fração de área de vegetação nativa a ser recuperada por imóvel. No estudo de caso, para 61 imóveis o IVNR apurado foi igual à zero, sendo que para os outros 15 variou de $0,1 \%$ a 94,0\%. Nas propriedades de até $01 M F$ (Módulo Fiscal), o IVNR foi de 1,3\%, maiores que 01 a $02 \mathrm{MF}$ ficou igual à zero, maiores que 02 a $04 M F$ foi de 1,5\% e nos acima de 04MF foi de 10,8\%. Para o total de imóveis pesquisados, IVNR mostrou que 9,2\% da área que deveria estar coberta com vegetação nativa precisa ser recuperada, pois se encontra desfigurada em termos de sua flora nativa. O método utilizado, ao revelar a situação de cada imóvel rural em relação ao cumprimento das diretrizes do novo Código Florestal, torna-se uma ferramenta de suporte das políticas de gestão territorial e ambiental.
\end{abstract}

Palavras-chave: Novo Código Florestal; Área de Preservação Permanente; Reserva Legal. 


\section{INTRODUCTION}

The strategy of Brazilian government to ensure sustainable use of natural resources on private lands has been based on the adoption of directives and control measures established in the Forest Code, especially regarding Permanent Preservation Areas (PPA) and 'Legal Reserves' (LR) (AZEVEDO, 2008).

According to the new Forest Code, Laws no. 12,651/ 2012 (BRASIL, 2012) and no. 12,727/2012 (BRASIL, 2012a), the margins of any watercourse are considered PPA, whose minimum width ranges from 30 to 500 meters, depending on the width of the watercourse bed. However, for properties sized up to 04 fiscal modules (FM) that are located in 'consolidated' rural areas, this width varies from 5 to 15 meters. Such consolidated area is understood as the "area of rural property with anthropic occupation that precedes July 22, 2008, having buildings, improvements or agroforestry-herding activities" (BRASIL, 2012; MACHADO, 2013).

Permanent Protection Areas adjacent to perennial springs and seeps shall have a minimum radius of 50 meters. But, on consolidated rural areas, just 15 meters of recomposition is required. In areas sized over 20 hectares surrounding lakes and natural ponds, the minimum width of PPA ranges from 50 to 100 meters, but on a consolidated rural area, the minimum width of required buffer strips ranges from only 5 to 30 meters (BRASIL, 2012; SODRÉ, 2013).

In terms of topography, areas located on slopes or parts thereof, with declivity above $45^{\circ}$, equivalent to $100 \%$ in the steepest line, are considered PPAs. Regarding hilltops, mountains and hills with a minimum height of 100 meters and average slope over $25^{\circ}$, the PPA areas are those defined by a contour line corresponding to $2 / 3$ of the minimum height, always relative to the base (BRASIL, 2012).

The implementation of Legal Reserve should aim to maximize both agricultural potential of the property and conservation of nature (DELALIBERA et al., 2008). The percentage of each property aimed at Legal Reserve varies by region and biome, being $20 \%$ for the state of Rio Grande do Sul(BRASIL, 2012). However, properties of up to four fiscal modules will be deemed compliant with Legal Reserve percentage requirement that was valid on July 22, 2008, in case this is lower than that mentioned above (ANTUNES, 2013; MUKAI, 2013).
The most beneficial rules, established by the current Forest Code, regarding the size of PPAs and LR for farmers who own up to four fiscal modules are justified on the grounds of their social importance for rural production, without, nevertheless, having much impact on environmental protection of significant part of the national territory (POLÍZIO JUNIOR, 2012).

Among its innovations, the current Code established that the PPAs of the property can be added in the calculation of the area aimed at Legal Reserve, provided that the owner has registered the property with the Rural Environmental Registry. Moreover, this calculation is only permitted if the area to be computed is either conserved or under recovery and if this addition will not entail further deforestation (POLÍZIO JUNIOR, 2012; MELO NETO, 2013).

Land use regulation is a critical component of forest management and conservation strategies. The ecological benefits of compliance are diffuse and can hardly compete with the economic benefits of non-compliance, which are easily perceived by landowners (STICKLER et al., 2013). Although the task of recovering any area of native vegetation falls to the farmer, the State should provide technical support for this task so that the whole collectivity will benefit from this process.

Society expects this Forest Code both to be a milestone catalyst for the compliance with directives related to the environment and to adapt to the reality of the country, in order to cope with the challenge of balancing agricultural production with environmental preservation (FIGUEIREDO, 2013). However, studies that evaluate the impact of the new rules set by the current Forest Code are still scarce, since this law has recently come into force.

In this context, this research seeks to contribute to deepen discussions on sustainable development. It aimed to propose a method for calculating the Native Vegetation Recovering Index (NVRI) for a farm and to validate it by means of a case study in the city of Porto Alegre/RS, drawing on the Technical Cadaster maintained by the City Hall and on the use of geotechnology. Considering the provisions of the current Forest Code, the proposed method enables to determine the fraction of the property area that shall be recovered by farmers in terms of native vegetation cover, in order to restore the environment that has been changed by agricultural activities. 


\section{MATERIALAND METHODS}

\subsection{Native Vegetation Recovering Index (NVRI)}

The determination of the NVRI requires measuring the area of native vegetation legally required on the farm. This area is the result of the dimensions of Permanent Preservation Areas and Legal Reserve for the property.

In the present study, when legislation permitted, it was considered the inclusion of PPAs in the calculation of LR. Then, based on the LR, it was defined the native vegetation area to be preserved and/or recovered on the farm in addition to that already registered as PPA.

NVRI is defined as follows:

$\mathrm{NVRI}=(([\mathrm{PPAwithoutNV}]+[\mathrm{NPA}]) /[\mathrm{NV}]) \times 100$

Where:

PPAwithoutNV: the fraction of PPA without native vegetation cover, in hectares;

NPA: area to be preserved with native vegetation that is located outside of the PPA, in hectares;

$\mathrm{NV}$ : total area of the property to be preserved with native vegetation, in hectares

NVRI: Native Vegetation Recovering Index for the rural property, in percentage.

\subsection{Study area}

Porto Alegre is the capital of Rio Grande do Sul, located between $29^{\circ} 10^{\prime} 30^{\prime}$ 'S and $30^{\circ} 10^{\prime} 00^{\prime}$ 'S in latitude and between $51^{\circ} 05^{\prime} 00^{\prime \prime} \mathrm{W}$ and $51^{\circ} 16^{\prime} 15^{\prime \prime} \mathrm{W}$ in longitude. It has an area of $496.684 \mathrm{~km}^{2}$ and a population of 1,409,351 inhabitants (IBGE, 2010). Its climate is classified as humid subtropical (according to Köppen), being remarkably characterized by a wide temperature variability. The city is divided into two biomes - mostly Pampa, and also the Atlantic Forest.

The case study was conducted in the southernmost region of Porto Alegre, due to both its specific characteristics and the availability of the necessary data. This region is located in in the Rururban Macrozone defined in the Master Plan for Urban Environmental Development of the municipality (PORTO ALEGRE, 1999). The city is bounded to the south and southwest by the Guaiba Lake, and to the east by the municipality of Viamão, an area characterized by wavy topography and mostly covered with Atlantic forest. Center and West sides comprise a flat region, bordering Guaiba Lake, where primary production activities are developed, particularly rice cultivation and livestock.

\subsection{Data collection and methodological procedures}

Porto Alegre City Hall provided the various levels of information required for conducting the research: (i) database of real estate cadastre for the researched area; (ii) QuickBird 2008 orbital image of the municipal area with spatial resolution of $0.60 \mathrm{~m}$; (iii) information on hydrography, real estate and altimetry at 1:5,000 scale; (iv) digital orthorectified aerial photography taken on August 2010 of the study area at 1:5,000 scale; (v) levels of information originating from digital photogrammetric coverage and laser scanning of the researched area held in August 2010, at 1:1,000 scale: native vegetation; hydrography; land occupation and contour lines. The version 10 of software ARCGIS was used for integrating these data into GIS (Geographic Information System). All data were referenced to SIRGAS2000 (Geocentric Reference System for the Americas).

Within the study area, 356 properties presenting rural characteristics were identified and subsequently classified by size according to the following strata: (a) up to 01 fiscal module (FM); (b) greater than 01FM and up to 02FM; (c) greater than 02FM and up to 04FM; and (d) greater than 04FM. These categories considered the fiscal module of five hectares defined for the city of Porto Alegre.

Following Barbetta, Kings and Bornia (2004), the calculated sample comprised 76 properties to be examined, for a confidence level of $95 \%$ and maximum tolerable error of $10 \%$, this latter stipulated as a function of time and resources available to the research. The properties to be studied were selected randomly, and proportionally distributed according to the number of existing properties in each stratum.

All sampled properties were considered as consolidated rural areas for purposes of the Forest Code provisions, insofar as the agroforestry-herding activities in this region are long-standing, what was confirmed especially by the analysis of the 2008 orbital image.

Data on forests provided by Porto Alegre City Hall were considered as native vegetation cover. In

Revista Árvore, Viçosa-MG, v.40, n.3, p.407-414, 2016

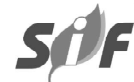


GIS, the floristic coverage of each property was determined through intersection of the polygon of the property with the layer of vegetation, which resulted in the native vegetation area for each property.

The analysis of the hilltops was based on contour lines, declivity was calculated through the SLOPE function of ARCGIS and results showed that the characteristics of topographic elements (height and steepness) do not qualify as PPAs. Thus, in the surveyed farms of this study area, the PPAs are qualified by hydrography elements: (i) waterways; (ii) springs and (iii) Guaiba Lake.

The PPAs by property, defined through BUFFER analysis in GIS, were intersected with the areas of native vegetation in each property in order to identify the dimensions of the PPAs by property and the fractions of these PPAs with and without native vegetation cover.

The definition of Legal Reserves considered successively: (i) native vegetation area located outside PPA; (ii) native vegetation area located within PPA; (iii) PPA area without native vegetation and, finally, (iv) area without native vegetation outside PPA. These criteria were sequentially applied so that to define the legal reserve area by property according to sizes established in the Forest Code. Thereafter, the size of the Legal Reserve was calculated, its coverage in terms of native vegetation was identified, as well as its location, in this case, inside or outside PPA. This procedure enabled to define all elements required for determining the NVRI according to section 2.1 .

\section{RESULTS}

Most of the surveyed properties has up to four fiscal modules, and $43.4 \%$ of the total has a maximum of 5 hectares. Table 1 shows the results for native vegetation cover, PPA and LR per size category and the total area of the surveyed properties.

Native vegetation covers, on average, $37.3 \%$ of the area of properties, reaching $50.8 \%$ for properties in the stratum of more than 02 up to 04 fiscal modules.

The fractions of Permanent Protection Areas occurring on the properties were identified by using the recommended technique, as well as its coverage in terms of native vegetation. The results of this stage of the work can be spacialized for each property, as exemplified for one property in Figure 1. Only 42 out of the 76 sampled properties showed incidence of PPA, whose area was estimated at 88.49 ha, and which is mostly located in larger properties. An area of 6.47 ha, or $7.3 \%$ of the total surveyed PPA, does not present native vegetation cover. For the two strata of properties with largest areas, the percentages of PPAs without native vegetation ranged from $7.3 \%$ to $7.7 \%$. In the stratum of properties with more than 01 up to $02 \mathrm{FM}$,

Table 1 - Area of native vegetation, Permanent Preservation Area (PPA) and Legal Reserve of sampled 76 rural properties per stratum (FM: fiscal modules).

Tabela 1 - Área de vegetação nativa, Área de Preservação Permanente (APP) e Reserva Legal dos 76 imóveis rurais amostrados por estrato (MF: módulos fiscais).

\begin{tabular}{|c|c|c|c|c|c|}
\hline \multirow[t]{2}{*}{ Parâmetros } & \multicolumn{5}{|c|}{ Properties strata by area } \\
\hline & $\leq 01 \mathrm{FM}$ & $\begin{array}{c}\geq 01 \text { to } \\
02 \mathrm{FM}\end{array}$ & $\begin{array}{c}\geq 02 \text { to } \\
04 \mathrm{FM}\end{array}$ & $>04 \mathrm{FM}$ & Total \\
\hline Number of properties & 33 & 11 & 14 & 18 & 76 \\
\hline Percentage of properties - \% & 43.4 & 14.5 & 18.4 & 23.7 & 100.0 \\
\hline Area of the properties - ha & 100.08 & 90.51 & 160.46 & $1,450.65$ & $1,801.71$ \\
\hline Area of the properties - \% & 5.6 & 5.0 & 8.9 & 80.5 & 100.0 \\
\hline Native vegetation - ha & 42.72 & 29.46 & 81.51 & 518.95 & 672.64 \\
\hline Native vegetation - \% & 42.7 & 32.5 & 50.8 & 35.8 & 37.3 \\
\hline PPA - ha & 2.18 & 1.37 & 7.69 & 77.25 & 88.49 \\
\hline PPA - \% & 2.2 & 1.5 & 4.8 & 5.3 & 4.9 \\
\hline PPA without native vegetation - ha & 0.25 & 0.00 & 0.59 & 5.63 & 6.47 \\
\hline PA without native vegetation - $\%$ & 11.5 & 0.0 & 7.7 & 7.3 & 7.3 \\
\hline Legal Reserve - ha & 19.75 & 15.29 & 30.16 & 290.04 & 355.24 \\
\hline Legal Reserve - \% & 19.7 & 16.9 & 18.8 & 20.0 & 19.7 \\
\hline Legal Reserve with native vegetation - ha & 19.75 & 15.29 & 30.16 & 255.91 & 321.11 \\
\hline Legal Reserve with native vegetation - \% & 100.0 & 100.0 & 100.0 & 88.2 & 90.4 \\
\hline Legal Reserve without native vegetationoutside PPA - ha & 0.00 & 0.00 & 0.00 & 34.13 & 34.13 \\
\hline
\end{tabular}

Revista Árvore, Viçosa-MG, v.40, n.3, p.407-414, 2016 
this percentage was zero, meaning that the required natural vegetation is being preserved in these properties. As to the stratum of properties with smallest areas, it showed the highest percentage (11.4\%) of PPA without native vegetation cover.

Legal Reserves on the studied properties represented, on average, $19.7 \%$ of the area, ranging from $1.8 \%$ to $20.0 \%$. Most of the area bound for LR is located outside PPA regardless of property size. Legal Reserve lacking vegetation cover was observed only for the stratum of the largest properties.

Data obtained enabled to calculate the NVRI. When calculated per property, the NVRI resulted zero for 61 of them; and, for the remaining, it ranged between 0.1 and $94.0 \%$ (Figure 2). Considering the properties above 04FM, 55.6\% of them presented an NVRI greater than zero, while for the remaining this percentage was $8.6 \%$.

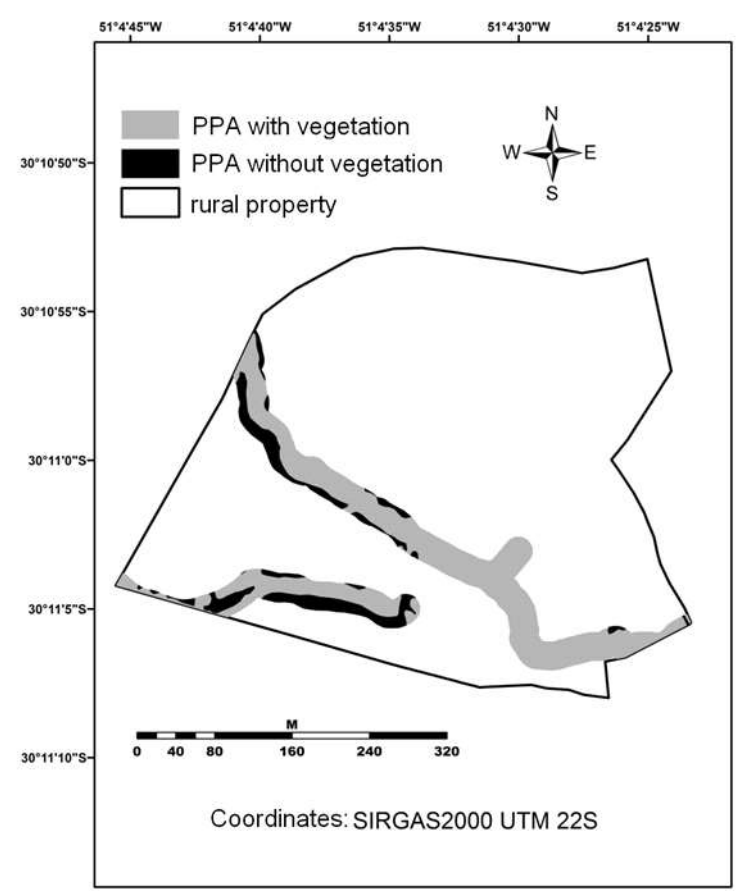

Figure 1 - Rural property of 19.216 ha and bearing 15 meters wide Permanent Preservation Areas (PPA) partially covered with native vegetation.

Figura 1-Imóvel de 19,216 ha e com incidência de Área de Preservação Permanente (APP) de 15 metros de largura parcialmente coberta com vegetação nativa.
Table 2 presents data grouped by stratum of area of the properties and the total of sampled properties.

Considering the 76 studied properties, it was estimated an area of 441.02 ha that should be covered with native vegetation on PPA and/or LR. Based on NVRI, it was estimated an area of $9.2 \%$ that should be recovered, for being disfigured in terms of native flora cover. This fraction corresponds to an area of 40.60 ha.

NVRI resulted much higher for the stratum of properties sized above $04 \mathrm{FM}$, reaching $10.8 \%$ on average. For the stratum sized more than 01 to $02 \mathrm{FM}$, the index resulted zero, therefore, no native vegetation area needs to be recovered. In the other two strata, the index varied, on average, from $1.3 \%$ to $1.5 \%$.

Figure 3 shows the spatial distribution of the surveyed properties, with the respective indication of the value range of VNRI found for each of them.

\section{DISCUSSION}

Geoprocessing makes possible the implementation of forestry legislation, especially concerning the delimitation and spatial distribution of PPAs (GONÇALVES et al., 2012). To this end, this research drew on such tool, succeeding in its objectives.

The determined average percentage of native vegetation by property indicates a high coverage, which largely results from the rugged terrain that characterizes the researched area and makes difficult the exploitation of agricultural activities. Pinheiro et al. (2011) obtained similar results, also noting that in flatter areas native vegetation cover is lower due to greater incidence of agricultural activities.

Nevertheless, in this hilly area, there were no PPAs resulting from relief (height and/or slope). Due to the change in the parameters that define PPAs in the current Forest Code, Oliveira and Fernandes Filho (2013) consider that elevations higher than 100 meters referred to the base (considering the closest saddle point) and, at the same time, average declivity greater than $25^{\circ}$ would hardly be found. This reduces the potential for environmental protection of the PPAs, especially in relation to hilltops and steep slopes (SOARES et al., 2011).

Out of the 42 properties which have a PPA, 31 $(73.8 \%)$ present the minimum coverage of native vegetation set by the Forest Code. This high rate of

Revista Árvore, Viçosa-MG, v.40, n.3, p.407-414, 2016

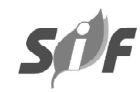


Table 2 - Native Vegetation Recovering Index of rural property (NVRI) per size stratum and total area of the sampled properties (FM: fiscal modules; PPA: Permanent Preservation Area).

Tabela 2 - Índice de Vegetação Nativa a Recuperar da propriedade rural (IVNR) por estrato de tamanho e total dos imóveis amostrados (MF: módulos fiscais; APP: Área de Preservação Permanente).

\begin{tabular}{|c|c|c|c|c|c|c|}
\hline \multirow[t]{2}{*}{ Parameters } & & \multicolumn{5}{|c|}{ Area stratum of the properties } \\
\hline & & $\leq 01 \mathrm{FM}$ & $\begin{array}{l}\geq 01 \text { to } \\
02 \mathrm{FM}\end{array}$ & $\begin{array}{l}\geq 02 \text { to } \\
04 \mathrm{FM}\end{array}$ & $>04 \mathrm{FM}$ & Total \\
\hline Number of propoerties & & 33 & 14 & 11 & 18 & 76 \\
\hline Required vegetation - ha & $\begin{array}{c}\text { On PPA } \\
\text { Outside PPA } \\
\text { Total }\end{array}$ & $\begin{array}{c}2.18 \\
17.06 \\
19.25\end{array}$ & $\begin{array}{c}1.38 \\
14.91 \\
16.28\end{array}$ & $\begin{array}{c}7.69 \\
30.42 \\
38.11\end{array}$ & $\begin{array}{c}77.25 \\
290.13 \\
367.38\end{array}$ & $\begin{array}{c}88.50 \\
352.52 \\
441.02\end{array}$ \\
\hline $\begin{array}{l}\text { Lacking required } \\
\text { vegetation - ha }\end{array}$ & $\begin{array}{c}\text { On PPA } \\
\text { Outside PPA } \\
\text { Total }\end{array}$ & $\begin{array}{l}0.25 \\
0.00 \\
0.25\end{array}$ & $\begin{array}{l}0.00 \\
0.00 \\
0.00\end{array}$ & $\begin{array}{l}0.59 \\
0.00 \\
0.59\end{array}$ & $\begin{array}{c}5.63 \\
34.13 \\
39.76\end{array}$ & $\begin{array}{c}30.35 \\
34.13 \\
40.6\end{array}$ \\
\hline NVRI & & $1.3 \%$ & $0.0 \%$ & $1.5 \%$ & $10.8 \%$ & $9.2 \%$ \\
\hline
\end{tabular}

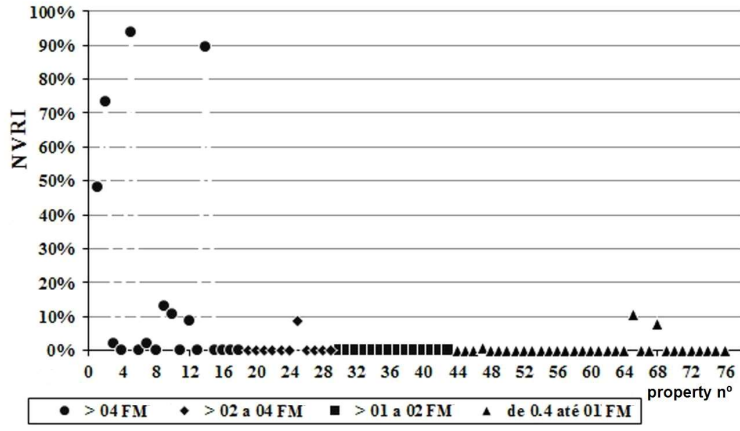

Figure 2 - Native Vegetation Recovering Index for rural property (NVRI) by surveyed property and by area stratum expressed in fiscal modules (FM).

Figura 2 - Índice de Vegetação Nativa a Recuperar da propriedade rural (IVNR) por imóvel componente da pesquisa e por estrato de área em módulos fiscais $(M F)$.

compliant properties is a consequence of both the good native vegetation cover existing in these properties and the new beneficial rules established for properties with up to 04FM.

Most of the area aimed at LR is located outside PPAs, regardless of property size. This happens because PPAs are present in just a partial number of the surveyed properties. Furthermore, the PPA can only be included in the LR if this will not entail the alternative of using the soil of area outside PPA that is covered with native vegetation.

Legal Reserve lacking vegetation cover was observed only for the stratum of larger properties. This is the tangible effect of the Forest Code special provisions for properties of up to $04 \mathrm{FM}$, for which the LR can be reduced to the area covered with native vegetation existing in July 2008. Thus, the LR of properties sized up to $04 \mathrm{FM}$ is compliant with legislation, i.e. it does not lack native vegetation cover.

In the scope of this research, the area outside PPA to be recovered with native vegetation must be related to area aimed at LR. Moreover, as a result of the special provisions aimed at properties sized up

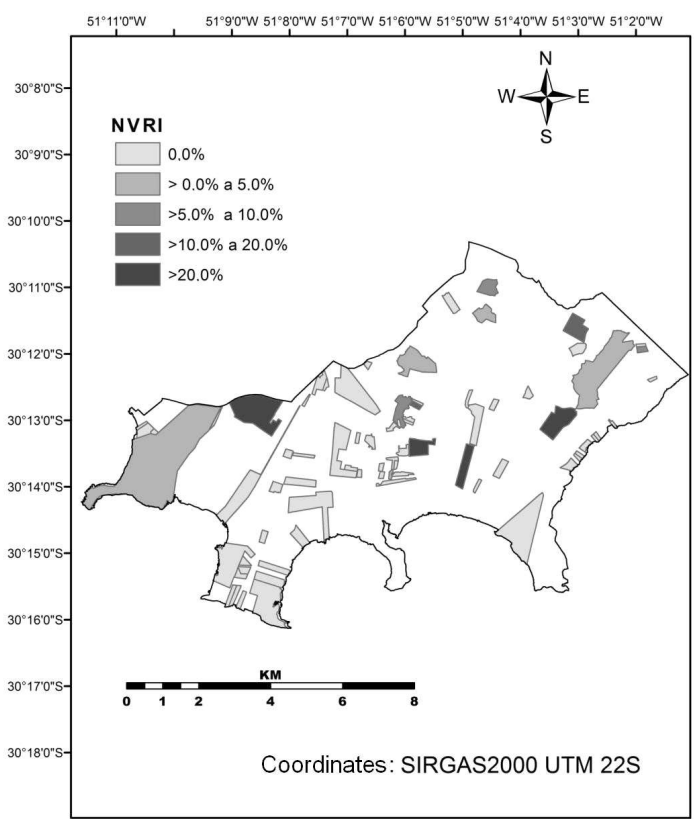

Figure 3 - Choropleth map of Native Vegetation Recovering Index of rural property (NVRI) for the surveyed rural properties.

Figura 3 - Representação coroplética do Índice de Vegetação Nativa a Recuperar (IVNR) para os imóveis rurais componentes da pesquisa. 
to 04 fiscal modules, only properties in the upper stratum, of over 04FM, have areas outside PPA to be recovered with native vegetation. Regarding these properties, 34.1 ha out of a total 290.13 ha, representing $11.8 \%$ of the area outside PPA aimed at being covered with native vegetation as LR, is lacking such cover and must, therefore, be recovered. Considering the global average for all sampled properties, this rate drops to $9.7 \%$, what reveals the influence in terms of area of the larger properties.

Most properties $(81.6 \%)$ has a null NVRI, so holds no requirement for recovering native vegetation areas, being compliant, in this respect, with the provisions of the Forest Code. Such compliance rate drops to $50.0 \%$ in the stratum of largest properties. However, for the strata of properties sized up to 04FM, that is, for the smallest properties, the compliance rate reaches $91.3 \%$. This shows that the special rules aimed at these properties reached their objectives, enabling most of them to conform to the Forest Code, in terms of native vegetation cover.

As it seems, there is no correlation between the location of the property and the calculated value of NVRI (Figure 3). This fact may be explained by the high percentage of properties with a null NVRI that are spread all over the study area. However, this fact deserves further studies, considering the agricultural activities on the properties as well as the hydrography and relief of the area.

\section{CONCLUSIONS}

This research aimed to propose and validate the method for calculating the Native Vegetation Recovering Index for rural property, and achieved its goal. The directives set by the new Forest Code regarding Permanent Preservation Areas and Legal Reserves were applied through the use of the adopted methodology.

The high incidence of properties sized up to 04FM that are in conformity with requirements for areas with native vegetation cover, and the major impact of properties sized over 04FM on the final value of NVRI, constitute relevant aspects that should be taken into account during public policies formulation.

The index method showed to be able of supporting public policies aimed at spatial and environmental management, by revealing the situation of each rural property regarding its compliance with the guidelines set in the new Forest Code.
It is recommended to apply this method to municipalities with cartographic and socio-spatial realities that are distinct from Porto Alegre, in order to find out whether the same positive results can be observed in other case studies.

\section{REFERENCES}

ANTUNES, P.B. Delimitação da Área de Reserva Legal. In: MILARÉ, É.; MACHADO, P.A.L. (Org.). Novo Código Florestal: Comentário à Lei 12.651, de 25 de maio de 2012, à Lei 12.727 , de 17 de outubro de 2012 e ao Decreto 7.830 , de 17 de outubro de 2012. 2. ed. São Paulo: Editora Revista dos Tribunais, 2013. p.229-255.

AZEVEDO, T.S. Legislação e Geotecnologias na Definição das Áreas de Preservação Permanente e das Reservas Legais: Aplicação à Bacia do Córrego das Posses, Município de Extrema - MG. 2008. 168 f. Tese (Doutorado) - Instituto de Geociências e Ciências Exatas, Campus de Rio Claro, Universidade Estadual Paulista, Rio Claro, 2008.

BARBETTA, P.A.; REIS, M.M.; BORNIA, A.C. Estatística para Cursos de Engenharia e Informática Engenharia e Informática. São Paulo: Atlas, 2004. 376p.

BRASIL. Lei n. 12.651, de 25 de maio de 2012. Dispõe sobre a proteção da vegetação nativa; altera as Leis $\mathrm{n}^{\text {os }} 6.938$, de 31 de agosto de 1981, 9.393, de 19 de dezembro de 1996, e 11.428, de 22 de dezembro de 2006; revoga as Leis $n^{\text {os }} 4.771$, de 15 de setembro de 1965 , e 7.754, de 14 de abril de 1989, e a Medida Provisória n ${ }^{\circ}$ 2.166-67, de 24 de agosto de 2001; e dá outras providências. 2012.

BRASIL. Lei n. 12.727, de 17 de outubro de 2012. Altera a Lei no 12.651 , de 25 de maio de 2012, que dispõe sobre a proteção da vegetação nativa. $2012 \mathrm{a}$.

DELALIBERA, H.C. Alocação de reserva legal em propriedades rurais: Do cartesiano ao holístico.

Revista Brasileira de Engenharia Agrícola e Ambiental, v.12, n.3, p.286-292, 2008.

FIGUEIREDO, G.J.P. Disposições Gerais. In: MILARÉ, É.; MACHADO, P.A.L. (Org.). Novo Código Florestal: Comentário à Lei 12.651, de

Revista Árvore, Viçosa-MG, v.40, n.3, p.407-414, 2016 
25 de maio de 2012, à Lei 12.727 , de 17 de outubro de 2012 e ao Decreto 7.830 , de 17 de outubro de 2012. $2^{\mathrm{a}}$. ed. São Paulo: Revista dos Tribunais, 2013.p.31-52.

GONCALVES, A. B.; MARCARTTI, E.G.; RIBEIRO, C.A.A.S.; SOARES,V.P.;MEIRA NETO, J.A.A.; LEITE, H.G.; GLERIANI, J.M.; LANA, V.M. Mapeamento das áreas de preservação permanente e identificação dos conflitos de uso da terra na sub-bacia hidrográfica do Rio Camapuã/Brumado. Revista Árvore, v.36, n.4, p.759-766, 2012.

INSTITUTO BRASILEIRO DE GEOGRAFIA E ESTATÍSTICA - IBGE. Censo Demográfico 2010. Available at: http:// www.censo2010.ibge.gov.br.

MACHADO, P.A.L. Delimitação das Áreas de Preservação Permanente. In: MILARÉ, É.; MACHADO, P.A.L. (Org.). Novo Código Florestal: Comentário à Lei 12.651 , de 25 de maio de 2012, à Lei 12.727 , de 17 de outubro de 2012 e ao Decreto 7.830 , de 17 de outubro de 2012. $2^{\mathrm{a}}$.ed. São Paulo: Revista dos Tribunais, 2013. p.155-176.

MELO NETO, J.E. Das disposições gerais incisos III a V e X. In: MILARÉ, É.; MACHADO, P.A.L. (Org.). Novo Código Florestal: Comentário à Lei 12.651 , de 25 de maio de 2012 , à Lei 12.727 , de 17 de outubro de 2012 e ao Decreto 7.830 , de 17 de outubro de 2012. $2^{a}$. ed. São Paulo: Revista dos Tribunais, 2013. p.166-141.

MUKAI, T. O novo Código Florestal: Anotações à Lei n ${ }^{\circ} 12.651$, de 25 de maio de 2012, coma as alterações da Lei 12.727 , de 17 de outubro de 2012, de 17 de outubro de 2012. Rio de Janeiro: Forense, 2013. 162p.
OLIVEIRA, G.C.; FERNANDES FILHO, E.I. Metodologia para delimitação de APPs em topos de morros segundo o novo Código Florestal brasileiro utilizando sistemas de informação geográfica. In: SIMPÓSIO BRASILEIRO DE SENSORIAMENTO REMOTO - SBSR, 16.; Foz do Iguaçu; 2013. Anais... Foz do Iguaçu: INPE, 2013. p.4443-4450.

PINHEIRO, A.; BERTOLDI, J.; VIBRIAN, A.C.; KAUFMANN, V.; DESHAYES, M. Uso do solo na zona ripária de bacias agrícolas de pequeno a médio porte. Revista Árvore, v.35, n.6, p.1245-1251, 2011.

POLÍZIO JUNIOR, V. Código Florestal comentado, anotado e comparado. São Paulo: Rideel, 2012. 436p.

PORTO ALEGRE. Lei Complementar n. 434, de 20 de dezembro de 1999. Dispõe sobre o desenvolvimento urbano no Município de Porto Alegre, institui o Plano Diretor de Desenvolvimento Urbano Ambiental de Porto Alegre e dá outras providências. 1999.

SOARES, V. P.; MOREIRA, A.A.; RIBEIRO, C.A.A.S.; GLERIANI, J.M; GRIPP JUNIOR, J. Mapeamento de áreas de preservação permanentes e identificação dos conflitos legais de uso da terra na bacia hidrográfica do ribeirão São Bartolomeu - MG. Revista Árvore, v.35, n.3, p.555-563, 2011.

SODRÉ, A.A. O novo Código Florestal comentado. Leme: J. H. Mizuno, 2013. 466p.

STICKLER, C. M.; NEPSTAD, D.C; AZEVEDO, A.A.; MCGRATH, D.G. Defending public interests in private lands: compliance, costs and potential environmental consequences of the Brazilian Forest Code in Mato Grosso. Phil Trans R Soc B, n.368, p.1-12, 2013. 